\title{
The Use of Verbal Language in Wardah Cosmetic Advertising
}

\author{
Somadi $^{1 *}$ dan Ikhwan M. Said ${ }^{2}$
}

\author{
1.2. Cultural Sciences Faculty, Hasanuddin University \\ *Corresponding author.Email: somadi.sosrohadi@civitas.unas.ac.id,
}

\begin{abstract}
Advertising language is the language of communication between producers and consumers. Advertising language has the form of verbal and nonverbal language. Verbal language is the spoken and/or written language used in advertisements. Verbal language in advertising uses the form of sentences, persuasion diction which has a communicative function. Diction in advertising prioritizes belief, trust, and the ability to persuade readers to use the advertised product. This study aims to examine the diction and style of verbal language in Wardah cosmetic advertisements. The diction in wardah cosmetic advertisements is directly related to the vocabulary of cosmetics and beauty tools. It is suspected that the use of diction in Wardah cosmetic advertisements comes from the absorption of foreign languages. In this regard, the results of this study include (a) the use of diction and vocabulary in the language of wardah cosmetics advertisements, (b) the delivery of message content, in the form of information appeals, emotional appeals, and motivational appeals. (c) the use of message style, in the form of association, metaphor, personification, allegory, simile, synecdoche, symbolic, and metonymy. With the right style of language, it can make the process of delivering product information from producers to consumers easier to understand.
\end{abstract}

Keywords: Indonesian, Foreign Language, Advertising Language Style, Wardah Cosmetics.

\section{INTRODUCTION}

Wardah advertisements are beauty advertisements used by young women in the modern century. The use of language in Wardah cosmetics has its own distinctive color according to its community. The language of young women who are now categorized as modern humans, has a distinctive color. This peculiarity is reflected in the diction and terms it uses. Distinctiveness is known from the type of word and choice of words. The types of words used in the language of Wardah cosmetics advertisements are mixed types of words between official Indonesian, official Indonesian, and foreign languages.

The mixing of Indonesian and English is the hallmark of the youth language. The language in Wardah's cosmetic advertisements reflects the wearer and usage. Thus, language use in young women reflects the social group in society. Therefore, it can be grammatically characterized by its users. The peculiarity is characterized by diction in the form of imperative sentences.

Considering that advertising language is a language that has a persuasive style to persuade potential buyers, the question arises whether Wardah's cosmetic advertising language uses the right structure and diction in accordance with the rules of the Indonesian language? This will be proven in research. For that, this research needs to be done.

Advertising is a form of communication from producers to consumers. Information about a product is better known as advertising. Through advertising, producers introduce their products to the wider community as potential consumers. The purpose of advertising is to make potential consumers interested in using the product. The use of Indonesian in advertising needs to be made more attractive, because it is used to offer a product. To influence buyers to buy the advertised product, the language that is often used in advertising is persuasive. 
For this reason, this paper focuses more on the use of Wardah cosmetic advertising language from the message, content and style of language used in it. A lot of research on advertising language has been done but it is still interesting because the advertising language continues to follow the development of the community.

\section{METODOLOGI}

\subsection{Previous Research}

To ensure that this research is not plagiarized, the following researchers present some of the results of previous research as follows. Diction and Language Style in Food Product Advertisements in Japan (Semiotic Studies) have been studied by [1]. In the study, diction was found that came from absorption words and foreign language terms. The language styles found in the data sources are Hyperbole, Metonymy, Personification, Synecdoche, Allusion, Simile, Alliteration, and Epizeuksis.

Research [2] on the Message of "Ramadan Television Advertising Creative". He found that the process of the message to be conveyed by the advertisement using the style of language in the advertisement was informative, because the advertisements studied were related to information about social messages from people's habits in the product and information about promotional programs held by the advertiser. .

Utami [3] researched "Style of Language in Product Advertising Texts with Associative Meaning of Pornography". The results of this study indicate that the meaning of features of pornographic product advertisements refers to the language code around intimate organs and intimate relationships which are represented in figurative forms, both in verbal and nonverbal elements.

Santoso [4] examines "The Meaning of Verbal and Nonverbal Messages in RCTI Public Service Advertisements". The research shows that verbal messages and non-verbal messages combine to form one advertising meaning, namely to stop the spread of hoaxes. Meanings that are difficult to understand in nonverbal messages are supported by verbal messages, and vice versa so that the meaning of advertising messages can be conveyed as a whole.

This research is different from previous research. This study is different because it will discuss diction in the form of persuasion that prioritizes a mixture of vocabulary between official Indonesian, popular Indonesian, and foreign languages in Wardah advertisements.

\subsection{Diction}

Style in the context of rhetoric is a distinctive, beautiful, and unique language. Therefore, the stylistic function is included in the poetic function. Jakobson in Utami [3] explains that the poetic function is the function of language to promote the flexibility of signs, emphasizing the fundamental dichotomy of signs and objects. In this context, it can be understood that the choice of language style in advertising has an associative meaning that refers to the product and its illustrations. Keraf [5] explains that language style considers (1) word choice, (2) tone contained in the discourse, (3) sentence structure, and (4) direct or indirect meaning. In this context, the researcher focuses on the suitability of the choice of words that give rise to discourse suggestions, sentence models, and their meanings. The use of figurative forms is a style of language that utilizes indirect meanings that have emotive and evaluative effects. Its construction and allusions reflect its effect and function

The meaning of words is not always static, from time to time the meaning of words can change [6]. Therefore, every language speaker must always pay attention to changes in meaning that occur. The kinds of changes in meaning that are important [6] include (1) expansion of meaning, meaning a process of changing meaning experienced by a word that previously contained a special meaning, but then expanded to encompass a wider class of meanings. general.

\subsection{Ad Language Barrel}

The language barrel is the suitability of the language and the function of the user. Laras Advertising Language has characteristics such as; there is the use of graphic elements and illustrations that are very prominent in printed advertisements, there is the use of moving images in the barrel of view-hearing advertisements on television and films. Meanwhile, Wresniati in Kencana [7] Laras language means the variety of languages (language user variants) used by a group of certain language users according to the suitability between languages. and its use. Each barrel can be delivered orally or in writing and in formal, semiformal, or informal forms. Therefore, in writing, we must master a variety of different tunings in order to choose the correct one for the target language group.

Roland Barthes [8] uses the term "the concept of duplicity" to provide an overview of advertising language that describes objects at the level of denotative and connotative relationships. Advertising language that gives more meaning to consumers so 
that it turns something simple into something special in their minds Barthes [8]. Laras Advertising language is used to influence consumers to have a certain response or change attitudes, and take action. The ad language barrel is also supported by verbal and nonverbal language. Verbal language in the form of spoken and written. Meanwhile, nonverbal language in the form of pictures, paintings, graphics, illustrations and others, according to the type of advertisement.

The ad language barrel has a style and a way of choosing words that match the characteristics of the ad. The use of language barrels can provoke a response or response from the audience. In selfpromotion, an entity, brand, or product must be able to place its image in order to enter the minds of consumers.

\section{ANALYSIS}

\subsection{Language Use In Wardah Advertising}

After collecting and classifying the language data in Wardah's advertisements, it shows that the use of vocabulary is always related to the cosmetic tools used on the organs of the head, namely that the marking relationship can be classified as described below. a) Wardah's cosmetic vocabulary for hair, b) Wardah's cosmetic vocabulary for face, c) Wardah's cosmetic vocabulary for eyes, c) Wardah's cosmetic vocabulary for lips, and e) Wardah's cosmetic vocabulary for social activities. The five elements in the cosmetic field have specific uses of words and terms by using language, vocabulary and terms. For that, it needs to be described as follows.

\subsubsection{Vocabulary in Wardah Cosmetics advertisement for hair section}

The use of vocabulary in Wardah's hair product is shampoo, which is a mixing language between English, official Indonesian, official Indonesian and foreign languages. Written verbal text, slowmo slowmo, the rest uses spoken language. Spoken text accompanies written text, product objects, or character movements in advertisements. The oral text is a narration of the products presented in Wardah cosmetic television commercials.

Example of spoken verbal text:

1. "It's stopped, no need to use slowmo again!"

2. "What are you wearing?"

3. "Wardah shampoo is halal, please, ma'am"

4. Hair looks healthy shine

Written verbal text, slowmo slowmo, is a spoken language. In the verbal text there is the word
Slowmo-Slowmo. This word is a form of interference from English into Indonesian. In English, called "Slow motion" the phrase consists of two words, "slow" and "motion". That is, the slow motion of the film. But in Indonesian it becomes plural and is repeated, "slowmo-slowmo". This is English. However, this expression is used in repeated Indonesian structures. Slowmo-slowmo verbal text is used by advertisers aimed at "youth" by using a mixture of English-English. The text of "slowmoslowmo", both in Indonesian and in English, is not a standard language. The expression above is a form of persuasion sentence (prohibition). Even if it contradicts the principle of promotion in advertising, the statement makes consumers feel curious.

\subsubsection{Wardah Cosmetics Products for Facial Skin}

The use of language in BB Powder "Dare to be natural no filter", (Dare to be natural, without filtering?)

then followed by the expression of spoken language, as follows.

"Dare to try, natural without filter? "(Dare to try, natural without filtering?"

The sentence should be completed as follows.

"Berari natural no filter"

a. Do you dare to look natural?

b. Do you dare to appear natural in public?

c. You dare to look natural without being filtered in public?

d. Do you dare to appear natural, without being filtered in public?

e. Do you dare to appear as you are in public?

In verbal texts, both spoken and written language is the repetition of concepts. In Indonesian, a repetition is used to emphasize something/information that will be conveyed. The text is in full English. This expression is used to convince the interlocutor or customer to be willing to use the offered BB cream product. When combined, the two clauses in Wardah Perfect Bright BB Powder \#Feel The Brighter You cosmetic product, display verbal text, both written language "Dare to be natural no filter" followed by spoken language, "Dare to try, natural without filter"?. The use of foreign languages such as "Cream" cannot be equated with "milk". However, Cream means ointment. Whereas in Indonesian there is the term "cream". 


\subsubsection{Wardah Cosmetics for the Eyes}

In the verbal text, the eye section is in English. Meanwhile, spoken language is a translation language from Indonesian. The use of these writings and expressions is in the form of phrases. In written verbal texts use English, while in spoken language expressions use Indonesian. In the text it says "Extra Volumizing" in English, which means extra and extra in Indonesian.

The verbal text shows that "BEFORE" and "AFTER" are written in full in English. The point is to show a striking difference between before and after wearing mascara. Before using mascara on the left side of the face, it looks original and natural. Meanwhile, after applying mascara, the right side of the face shows thicker eyebrows and darker eyelashes.

Both written and spoken texts use a mixture of Indonesian and English or English-English. This type of vocabulary is the language of "teenagers" or teenage girls.

\subsubsection{Wardah Cosmetic Products for Lips}

As it is known that the function of Exclusive matte lip cream is to make the lips not look chapped, so that the appearance becomes more luxurious, makes the feeling more comfortable and is also used to beautify the appearance of young women.

The solution for dry lips is still beautiful, the only halal lip product that is comfortable and long lasting on the lips for every activity. For this reason, Wardah Colorfit Velvet Matte Lip Mousse is the only halal lip product that is comfortable and long lasting on the lips for every woman's activity. This product has a comfort matte finish, which is a matte finish but doesn't feel sticky and dry or make lips look chapped. The fact is because this product is equipped with a new texture innovation Velvet Powdery, which feels soft, light and moist on the lips.

Verbal use only Written text "No Transfer" (not faded). The use of the word "No Transfer" in English in the new formula lipstick and means that it will not fade, it can be ascertained that the use of English is the dominance of the advertising language, considering that the target is young women. Therefore, the use or use of English is more emphasized.

\subsubsection{Wardah Cosmetics Products section Social Activities}

In the social activity group, the author only noted that there were 2, namely a) Ramadan 2019 "Always Thankful", b) 3 Minute Make up Challenge
Instaperfect by Wardah. This group can be categorized as "tips" because it provides a comprehensive technique of using Wardah cosmetics in just 3 minutes. Meanwhile, as a beautiful reflection from the inside, it is displayed in the form of activities in the community as well as a representation of Wardah's beauty from within, namely activities at the Nursing Home and Panti Tunawicara.

A group of mute children is learning to express gratitude with sign language. The gratitude that is always expressed will make people always excited, cheerful as shown by the teacher, a young woman. Apart from verbal texts, nonverbal texts support an atmosphere of speaking with the mute. Gratitude and joy are a reflection of the beauty in Wardah's heart.

Thus, the use of language in wardah cosmetic advertisements uses foreign words and terms, in the form of slowmo slowmo for hair cosmetics, no filter on the powder on the face, cream on powder, extra volumizing-before-after on mascara use, no transfer on applying lipstick, and 3 minutes for applying make-up.

Those are all words and terms in the language of advertising in the cosmetic field. For that, there is a specificity in the use of words and istikah in the cosmetic field. Thus, a glossary and/or cosmetic dictionary is required.

\section{CONCLUSION}

The use of language in wardah cosmetic advertisements uses non-standard Indonesian and mixing foreign languages, especially English. The use of foreign languages is a mixture of Indonesian and English. Producers use foreign languages by mixing Indonesian to win the hearts of wardah consumers. Wardah's customers are mostly young women. Manufacturers use popular language as a means of propaganda. As a dynamic in the cosmetic field, language must evolve. The development of the vocabulary of terms, and new language styles follow the community. The use of language, vocabulary, and terms in the field of cosmetics has a special characteristic. Vocabulary development must be in accordance with the demands of the times.

\section{AUTHORS' CONTRIBUTIONS}

The authors' contribution explains the mastery competence of the three modalities (repeating, reading, and writing) for non-fluent aphasia sufferers increased from time to time 


\section{ACKNOWLEDGMENTS}

We would like to thank several parties, specifically the Wardah's Group, Ramadan 2019 and a group of mute children, thank you for being informant in our research. The government of the director general of

\section{REFERENCES:}

[1] Rusmiyati. 2019. Diksi dan Gaya Bahasa Pada Iklan Produk Makanan di Jepang (Kajian Semiotika).

[2] Novan Andrianto. 2017. Pesan Kreatif Iklan Televisi Ramadan 2017: Analisis Isi Iklan "Bahagianya Adalah Bahagiaku" . Jurnal Studi Komunikasi. ISSN: 2549-7294, 2549-7626

[3] Utami, Sri Wiryanti Budi. 2019. "Gaya Bahasa dalam Teks Iklan Produk Bermakna Asosiatif Pornografi (Language Style in Pornographic Associative Advertising Text)". Mozaik Humaniora Vol. 197 Oktober 2019.

[4] Santoso, Budi "Analisis Makna Pesan Verbal Dan Pesan Non Verbal Dalam Iklan Layanan Masyarakat " RCTI. Prosiding. Universitas Dian Nuswantoro. 2019.

[5] Keraf, 2004. Diksi dan Gaya Bahasa. Jakarta: Gramedia Pustaka Utama.

[6] Keraf, Gorys. 2002. Diksi dan Gaya Bahasa. Jakarta: Gramedia Pustaka Utama.

[7] Kencana, Feby Puspa. 2019. "Karakteristik Laras Bahasa Dalam Media Sosial Instagram" Jurnal Diksatrasia Vol 3 No. 2 Juli 2019.

[8] Barthes, Roland. 1991. The Fashion System, terj. Matthew Ward dan Richard. Howard. Berkeley CA: University of California. higher education through Unhas for its financial assistance. 